\title{
FACTORS INFLUENCING EMPLOYEES TO COMMIT FRAUD IN WORKPLACE EMPIRICAL STUDY IN INDONESIAN HOSPITALS
}

\section{ARTICLE INFORMATION}

Article history:

Received July 31, 2015

Revised November 31, 2015

Accepted January 15, 2016

\section{JEL Classifications}

K42

\section{Key Words:}

Fraud,

Love of money,

Commitment,

Leadership,

Work environment,

Religious faith,

Organizational culture.

\section{DOI:}

10.21532/apfj.001.16.01.01.01

\author{
Aditya Pandu Wicaksono \\ Dekar Urumsah \\ Islamic University of Indonesia \\ E-mail: aditpandu@gmail.com
}

\begin{abstract}
Fraud is a part of unethical behavior which occurs around the world. It occurs because of some factors. This study aims to analyze the factors influencing fraud intention. This research use survey method by distribute questionnaire to respondent with convenience sampling to collect data. The questionnaires fill completely by 154 non-medical employees in some hospitals in Yogyakarta, Indonesia. SmartPLS 2.0 is used to analyze the statistics. The result of the study indicates that organizational commitment and morality leadership have positive effect against fraud intention. Meanwhile, love of money, morality leadership, work environment, religious faith, and organizational culture have negative effect against fraud intention. This research provide the influence of financial and nonfinancial factors to fraud intention and results can be guideline to protect organization from unethical act.
\end{abstract}

\section{INTRODUCTION}

Fraud is a crime occurred in the whole world, including Indonesia. Transparency International ranked Indonesia to 107 of 175 countries with a value of Corruption Perception Index (CPI) 34 below Singapore, Malaysia, Philippines, and Thailand. CPI ranks the countries based on how often corruption occurs in the public sector. CPI value scale starts from 0 (highly corrupt) to 100 (very clean). Low score of Indonesia's CPI can be concluded that Indonesia is the country with many fraud-cases among South East Asia country (Transparency International 2014).

According to Report to the Nation from the Association of Certified Fraud Examiners (ACFE) in 2014 reported 
that $42 \%$ of perpetrators of fraud committed by employees-level, managers committed $36 \%$ of the fraud, and $19 \%$ by the owners / executives. Looking at median loss, the biggest loss caused by owner / executive although had the fewest number of fraud-cases. Their median loss approximately four times higher than the median loss caused by managers, and nearly seven times that of employee. Based on industry, mining industry had fewest corruption cases with 13 cases, but mining industry had the greatest losses. In 2014, mining industry suffered $\$ 900,000$ in median loss caused by fraud. In banks and financial services industry, there were 244 cases of fraud with median loss of \$200,000 (ACFE 2014).

Research found that the love of money were the root of fraud (T. L. P. Tang and Chiu 2003) and love of money were a mediator to unethical behavior (E. G. Sardžoska and Tang 2012). Further described by Tang and Chiu (2003), organizational commitment of employees had not relation to fraud if employees satisfy with their salary. Sardžoska and Tang (2012) used the Theory of Planned Behavior to identify factors stimulated fraud behavior. Work environment were applied to investigating the effect of the work environment according to three dimensions: (1) relationship, personal growth or goal orientation, and (3) system maintenance and system change. This research explores and investigating factors that influence employees to commit fraud not only in financial area, but also non-financial factors such as influence from other person, religious faith, and culture of organization. It became an important investigation because fraud does not only stimulated by financial reason but also other people, work environment, religious faith, and organizational culture.

The objectives of this research are to confirm factors influencing employees' intention to commit fraud with Theory of Planned Behavior as basis of research model. This research use financial and non-financial factors to investigate intention to commit fraud. This research is organized as follows. First part is theoretical background and hypothesis development. Next part is the research methodology and data collections that will be used in this research. The final part is discussion of the finding, contribution, implication, limitation, and the suggestion for the future research.

\section{THEORETICAL BACKGROUND AND HYPOTHESIS DEVELOPMENT}

\section{Theory of Planned Behavior (TPB)}

TPB is an extension of The Theory of Reasoned Action (TRA) (Fishbein and Ajzen 1975). TPB presented a model describing the factors stimulated person emerging a behavior. In this theory, there were three important factors motivating people to had a intention to behavior before become an actual behavior. Three important factors were attitude toward behavior, subjective norms, and perceived behavioral control. Intentions were assumed to capture motivational factors that influence a behavior. They were indications of how hard people were willing to try, how much people's effort to perform the behavior (Ajzen 1991).

Attitude toward behavior refers a person has a favorable or unfavorable to perform or not 
perform the behavior (Ajzen 1991). According to TRA model, attitude toward behavior were a people belief before they actually perform a behavior. Belief links the behavior to a certain outcome or other attribute (such as cost to performing behavior) and since the attributes to be linked to the behavior, a person already valued positively or negatively to perform the behavior. Subjective norms is a social factors, it refers a person perception about important individuals or groups influence the behavior. A person tend to imitate how the referent perform the behavior. Perceived behavioral control refers person perception of the eases or difficulties of performing behavior that assumed reflect past experience or information from others such as friend's experience. The more favorable the attitude and subjective norms, and the greater perceived behavioral control, should be an intentions to perform the behavior (Ajzen 1991).

This research uses TPB to identifying intention to commit fraud. However, This research does not investigate actual behavior in fraud area. We suppose person have a intention and he/she has willingness to transform his/her intention become the actual behavior (Ajzen 1991; Grandberg and Holmberg 1990).

\section{Attitude Toward Behavior}

\section{The Love of Money}

Money is the instrument of commerce and the measure value (Tang 2007). Money had been used in the world for a long time. Managers use the money to attract, hold, and motivate employees to achieve organizational goals (Luna-Arocas and Tang 2004). Money is a motivator to evil (unethical behaviors) (Sardžoska and Tang 2012; Tang and Chiu 2003). Studies have been conducted to determine relation of love of money in manager-level (Sardžoska and Tang 2009), in public and private companies and based on gender (Sardžoska and Tang 2012). There are the questions, "Is money the important things?" and "Is money a symbol of success?". A very important question is "what is love money?" and "how to measure the love of money" (Luna-Arocas and Tang 2004).

Money Ethic Scale (MES) is developed by the results of researches: money is a need, positive or negative behavior towards money, money control, and obsession. Money Ethic Scale (MES) consist of six factors: good, evil, achievement, respect, budget, and freedom ( $\mathrm{T}$. L. Tang and Chen 2008; Du and Tang 2005; Luna-Arocas and Tang 2004). This research adopts "the love of money scale" (LOMS) (Tang et al. 2008; Sardžoska and Tang 2012) by four specific factors (part of the money ethic scale): motivator, successful, importance, and rich. The love of money scale reflect the symptoms that money is a motivator, symbol of success, money is important things and money to make person to be rich. Love of money is defined as behavior towards money from individuals including affective, behavioral, and cognitive components. The meaning of the love of money is a aspiration or obsession for money but not person's need, greed, or materialism (Sardžoska and Tang 2012).

Love of Money is the root of evil (unethical behavior) (Sardžoska and Tang 2009; Sardžoska 
and Tang 2012; Tang and Chiu 2003). Tang and Chiu (2003) used employees in Hong Kong as participants, their research found love of money negatively related to pay satisfaction. It means employees with high the love of money have a low of pay satisfaction (Tang and Chiu 2003). Employees with higher income have low level of the love of money. Tang et al. (2004) found that the love of money is mediator between income and salary satisfaction. The high and low level of love of money have different patterns of pay satisfaction and income. ACFE in survey found living beyond means is the reason a person to commit fraud (ACFE 2014). It means perpetrators has a high love of money to fulfill what they want and their lifestyle.

Hypothesis 1: Love of money will be positively related to fraud intention.

\section{Organizational Commitment}

Organizational commitment has been identified as a critical factor to know and explain work-related behavior (Bakshi, Kumar, and Rani 2009). Allen and Mayer (1990) conceptualized three component of organizational commitment:

1. Affective (Employee's emotional attachment, identification, and involvement in the organization)

2. Continuance (Commitment based on the costs that the employee associates with leaving organization).

3. Normative (Employee's feelings of obligation to stay with the organization).

Organizational commitment is a loyalty to the organization involving an active relationship with the organization so that individuals are willing to contribute to the organization. Organizational commitment is a consequence that appear based on job satisfaction. Commitment has associated in three factors: (a) a strong belief in and acceptance of the organization's goals and values, (b) a willingness to exert considerable effort and behalf of the organization, and (c) a strong desire to maintain membership in the organizations (R. T. Mowday, Steers, and Porter 1979). To measure it, Organizational Commitment Questionnaire (OCQ) is developed to understand level of employees' commitment and the pride be a part of the organization. The finding of previous research showed the love of money has negatively influence to pay satisfaction. It means the low of the love of money has a high pay satisfaction. Employees with high pay satisfaction less to commit fraud or unethical behavior in organizations. Explained further that high of pay satisfaction will create organizational commitment of employees. Organizational commitment not related to unethical behavior but employee's commitment will not deter evil or unethical behavior (Tang and Chiu 2003).

Hypothesis 2 : Organizational commitment will be negatively related to fraud intention.

\section{Subjective Norms}

\section{Morality Leadership}

Leadership is a drive toward organizational goals. There is a people's question "what is leadership?" And the implicit question "what is ethical leadership?". Leader must have something that can influence others to achieve 
goals. Leader were not only competent but also ethical in everyday conduct (Ciulla 1995). Leadership is more than a skill, more than knowledge of theory, more than analytical faculties. It is an ability to act purposively and ethically as the situation requires on the basis of the knowledge universals, experience, perception, and intuition. Ethical leadership should be based on the effective and successful for a long time. Leaders must demonstrate the highest standard of moral and ethical conduct in every day in talks, behavior, actions, and make decisions so that others in the organization can follow (Toor and Ofori 2009).

Ethical leadership is defined as the demonstration of normatively appropriate conduct through personal actions and interpersonal relationships, and promote such behavior on his followers through two-way communication, reinforcement, and decisionmaking. The first part of the definition is demonstrating behaviors that normatively appropriate (moral person) and the second part promote such behavior to followers (moral managers) (Toor and Ofori 2009). Ethical leadership has two dimensions: moral persons and managers. Moral persons are normatively appropriate conduct such that they appear honest, trustworthy, and credible to others. Moral managers means that the leader openly and explicitly talk about ethics and influencing the behavior and beliefs of employees (Brown, Trevino, and Harrison 2005). According to Ladkin (2008) "leading beautifully" has three dimensions: "mastery" in understanding the self and the context, "coherence" is congruence between various forms of self and one's purpose and message, "purpose" is attending to one's goals.

In order to reduce the number of unethical behavior in organizations, several studies were performed to examine the role of moral leadership to reduce unethical behavior. Mayer, Kuenzi, and Greenbaum (2011) conducted a study to examine the relationship between ethical leadership, ethical climate, and misconduct. These results indicate that ethical leadership is positively related to ethical climate and ethical climate negatively associated with misconduct. This means that the ethical leadership will make ethical atmosphere in the organization. Ethical climate will avoid unethical behavior. This research will examine the moral influence of a leader in relationship to fraud intention.

Hypothesis 3 : Morality leadership will be negatively related to fraud intention.

\section{Work Environment}

Work environment is about everything influence employees in the workplace (Taiwo 2009). Work environment describe how the situation in workplace influence employees' behavior. A person involved in one environment will imitate what person see in that environment. For example, if person involved in ethical environment so person will conduct ethically.

According to subjective norms in TPB normative. Ajzen (1991) explain individuals or groups of referent approve or disapprove to perform the behavior. In work environment a 
person will tend to adjust to what has become a culture in a company. A person will be indirectly influenced by a work environment to follow the culture in this environment. As an example, suppliers give a things to employee in order to accept their offers. Because it is the habit in environment so this gratuities becomes a natural thing and employees have justification to approve this gratuities.

Amabile et al. (1996) asserts that an favorable work environment create creativity, ethical behavior and performance of employees. A favorable environment increase of work satisfaction, commitment, and performance. According to Sardžoska and Tang (2012) a favorable working environment will generate job satisfaction and negatively related to corrupt (unethical behavior). This research will examine the direct path of work environment to fraud intention and find out how work environment influencing employees to perform ethical or unethical behavior.

Hypothesis 4 : Work environment will be negatively related to fraud intention

\section{Perceived Behavioral Control}

\section{Religious Faith}

Religious faith is a belief to God who creates and controls the universe. Glock and Stark (1965) defines religion as a system of symbols, belief systems, value system, and a system of behavior. Religious faith divide to 5 dimensions are experiential, ritualistic, ideological, intellectual, and consequential. There is a question of "Is morality possible without religion?". Although people without religion can do good deeds, then what the basis of moral norms underlie their actions? may be everything is permissible without God.

The relation between morality and religion is the complex thing. Religion may refer to a set of belief involving supernatural agent, code of conduct, set of rituals and self transcendent experiences, or sense-belonging in a community of believers. Morality refers to prosocial behavior (an aspect of practical ethics), intuitive and reflective judgment of act as rights, permissible or wrong (normative ethics) or beliefs about the basis on moral can be true or justified (meta-ethics) (Yilmaz and Bahçekapili 2015). Researchers assume that religion can be a deterrent to unethical behavior. In religion there is a prohibition to do unethical because it is a sin. There are the different of religious faith one person with others. Someone with high level of religious faith not to conduct unethical behavior because they believe unethical is prohibited by their religion. To measure religious faith, Mature Religiosity Scale (MRS) (Vries-Schot, Pieper, and Van Uden 2012) was developed to ask how religious influence person in his life. MRS provides the criteria for the assessment of a person's faith.

Hypothesis 5 : Religious faith will be negatively related to fraud intention.

\section{Organizational Culture}

Culture is an abstraction, yet the forces that are created in social and organizational situations that derive from culture are powerful. If don't understand the operation of these 
forces, we become victim to them (Schein 2004). Organizational culture represents an active, living, phenomenon by key members of the organization, such as executives create a culture and shared to other members to how to conduct. Member continuously interpret aspects of their work environment and these interpretation, as well as the ways in which they are enacted, form the organizational culture.

Organizational culture is a complex combination of formal and informal systems, processes, and interactions (Cohen 1993). Organizational culture consists formal component of the leadership, structure, policies, reward systems, mechanisms of socialization, and the decision process among other things. Formal organizational culture means organizational culture is formed from the direct and explicit process and set to be culture in the organization. Informal organizational culture including implicit behavioral norms, role of models, rituals, and language (Schein 2004). Informal elements of the culture is intangible of organizational behavior such as norms of behavior consistent with ethical standards or code of conduct (Trevino and Brown 2004). Researchers assert that organizations embed a culture for employees to perform an appropriate behavior in organization. A fraud can occur when a bad thing in an organization become a habit. This research will examine the direct path organizational culture to fraud intention and hypothesize that good organization will reduce fraud intention.
Hypothesis 6 : Organizational culture will be negatively related to fraud intention.

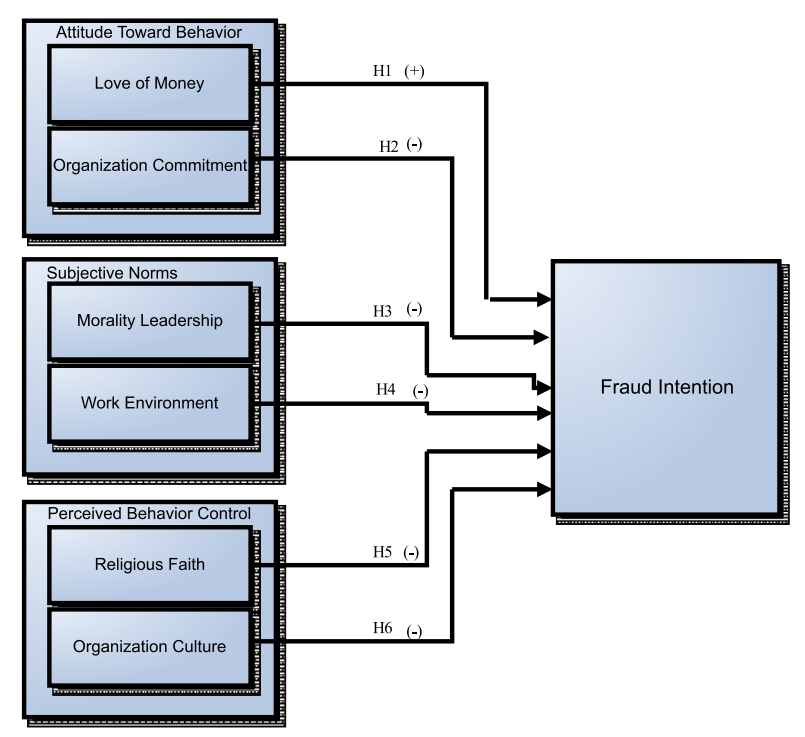

Figure 1.

Model Development

\section{RESEARCH METHODS}

\section{Research Method and Data Collection}

This research is a quantitative research approach by using survey method. Survey method is a technique of data collection by giving questions to individual respondents. In this research, the sample are non-medical employees of hospitals in Yogyakarta, Indonesia with convenience method to collect data by distribute questionnaires to respondents and distributed 170 questionnaires to the respondents, 154 filled completely. Complete data from 117 employees, 24 supervisors and 13 managers. In the questionnaire, the participants complete the questionnaire voluntarily and anonymously. Exploratory and confirmatory factor analysis are used in this research assessed by examining validity and composite reliability with Partial Least Square (SmartPLS 2.0). 


\section{Operational Definition and Variable}

\section{Measurement}

To measure the indicator of the variables in this research, the Likert scale with interval 1-6 is used, from Strongly Disagree to Strongly Agree. Next, the attributes and the indicators are put into the questionnaire by giving scores for each item in the questions asked as presented in table below:

\section{DATA ANALYSIS AND DISCUSSION}

Exploratory and confirmatory factor analysis were used in this research assessed by examining validity and composite reliability with Partial Least Square (SmartPLS 2.0) which are, Measurement Model (Outer Model) with validity and reliability test and Structural Model (Inner Model) with r-square and t-statistic test.

Table 1.

Operational Definitions

\begin{tabular}{|c|c|c|c|}
\hline Variable & Operational Definition & Measurement & References \\
\hline The love of money & $\begin{array}{l}\text { The love of money refers money is a } \\
\text { motivator, that money represent } \\
\text { success, money is important thing, } \\
\text { and willingness to be rich. }\end{array}$ & 13 items & $\begin{array}{c}\text { (Tang and Chiu 2003; } \\
\text { Sardžoska and Tang } \\
\text { 2012) }\end{array}$ \\
\hline $\begin{array}{l}\text { Organizational } \\
\text { Commitment }\end{array}$ & $\begin{array}{l}\text { Organizational commitment is a } \\
\text { loyalty of employee in organization } \\
\text { and employee give contribution to } \\
\text { organization. }\end{array}$ & 8 items & $\begin{array}{l}\text { (Mowday, Steers, and } \\
\text { Porter 1979) }\end{array}$ \\
\hline $\begin{array}{l}\text { Morality } \\
\text { Leadership }\end{array}$ & $\begin{array}{l}\text { This variable measure role of leader } \\
\text { to influence and to be a referent of } \\
\text { employee to perform behavior. }\end{array}$ & 7 items & $\begin{array}{c}\text { (Chen and Chen 2013; } \\
\text { Kaptein 2008) }\end{array}$ \\
\hline Work Environment & $\begin{array}{l}\text { Work environment refers to } \\
\text { environment in organization } \\
\text { influence employee to conduct the } \\
\text { behavior. }\end{array}$ & 7 items & (Kaptein 2008) \\
\hline Religious Faith & $\begin{array}{l}\text { Religious faith is used to understand } \\
\text { the rela tionship between employee } \\
\text { and God and God's influence in } \\
\text { employee's attitude. }\end{array}$ & 8 items & $\begin{array}{l}\text { (Vries-Schot, Pieper, } \\
\text { and Van Uden 2012) }\end{array}$ \\
\hline $\begin{array}{l}\text { Organizational } \\
\text { Culture }\end{array}$ & $\begin{array}{l}\text { This variable refers culture is implicit } \\
\text { rules in organization and how this } \\
\text { culture influencing and creating } \\
\text { employees to perform ethical } \\
\text { behavior. }\end{array}$ & 6 items & (Kaptein 2008) \\
\hline Fraud intention & $\begin{array}{l}\text { Fraud intention is a intention of } \\
\text { employee to perform unethical } \\
\text { behavior (fraud) }\end{array}$ & 6 items & $\begin{array}{l}\text { (Robinson and } \\
\text { Bennett 1995) }\end{array}$ \\
\hline
\end{tabular}


Measurement Model (Outer Model)

Validity Test

The validity test in this research used the convergent validity dan discriminant validity tests. Convergent validity is a measurement model based on the correlation between the item score with construct score. According to rule of thumb, to fulfill convergent validity score of Average Variance Extracted (AVE) have more than 0,50 .
While the test using discriminant validity is done by comparing the value of square root of average variance extracted (AVE) of each construct with correlation between constructs in the model. If the square root of AVE of each construct is bigger than the value of correlation between constructs, it can be conculded has fulfilled discriminant validity test.

Table 2.

Item Loadings and AVE

\begin{tabular}{|c|l|c|c|c|}
\hline Variable & \multicolumn{1}{|c|}{ Indicator } & Code & Loading & AVE \\
\hline \multirow{4}{*}{$\begin{array}{c}\text { Love of Money } \\
\text { (LOM) }\end{array}$} & Money is symbol success & LOM4 & 0.6999 & \\
\cline { 2 - 4 } & Money represent my achievement & LOM5 & 0.6753 & \\
\cline { 2 - 4 } & Money is compare with other & LOM6 & 0.7974 & \multirow{3}{*}{0.5109} \\
\cline { 2 - 4 } & Money is motivator & LOM7 & 0.6058 & \\
\cline { 2 - 4 } & I motivated to work harder for money & LOM9 & 0.7333 & \\
\cline { 2 - 4 } & If I rich, I will be enjoy & LOM13 & 0.7609 & \\
\hline $\begin{array}{c}\text { Organiational } \\
\text { Commitment } \\
(\text { OCO) }\end{array}$ & Organization inspires very best in me & OCO6 & 0.7475 & \\
\cline { 2 - 4 } & Really care about organization & OCO7 & 0.8770 & \multirow{2}{*}{0.6878} \\
\cline { 2 - 4 } $\begin{array}{c}\text { Morality } \\
\text { leadership } \\
(\text { ML) }\end{array}$ & The best organization in my carrier & OCO8 & 0.8576 & \\
\cline { 2 - 4 } & My leader is a good example & ML1 & 0.7209 & \\
\cline { 2 - 4 } & My leader is honest person & ML2 & 0.7938 & \\
\cline { 2 - 4 } & My leader don't get personal benefit & ML3 & 0.7109 & \\
\cline { 2 - 4 } & My leader fulfills his responsibilities & ML5 & 0.7459 & \\
\cline { 2 - 4 } & My leader never authorize unethical & ML7 & 0.6179 & \\
\hline
\end{tabular}

Table 2. Continued

Item Loading and AVE

\begin{tabular}{|c|l|c|c|c|}
\hline Variable & \multicolumn{1}{|c|}{ Indicator } & Code & Loading & AVE \\
\hline \multirow{3}{*}{$\begin{array}{c}\text { Work } \\
\text { Environment } \\
(\text { WE) }\end{array}$} & Atmosphere of mutual trust & WE1 & 0.8218 & \\
\cline { 2 - 4 } & Interest with organization at heart & WE2 & 0.7130 & \\
\cline { 2 - 4 } & $\begin{array}{l}\text { Mutual trust between employees and } \\
\text { management }\end{array}$ & WE3 & 0.7602 & 0.5720 \\
\cline { 2 - 4 } & Unethical handled seriously & WE7 & 0.7256 & \\
\hline
\end{tabular}




\begin{tabular}{|c|c|c|c|c|}
\hline \multirow{7}{*}{$\begin{array}{l}\text { Religious Faith } \\
\text { (RF) }\end{array}$} & I entrust more and more to God & RF1 & 0.8228 & \multirow{7}{*}{0.5387} \\
\hline & My religion supports my self & RF2 & 0.6743 & \\
\hline & God is the basis of life & RF3 & 0.7665 & \\
\hline & Relationship with God & RF4 & 0.6238 & \\
\hline & God motivates the best & RF5 & 0.6907 & \\
\hline & Believe to God when have difficult & RF6 & 0.7369 & \\
\hline & Responsibility to God & RF7 & 0.8016 & \\
\hline \multirow{4}{*}{$\begin{array}{l}\text { Organizational } \\
\text { Culture (OCU) }\end{array}$} & People responsible with their act & OCU1 & 0.6958 & \multirow{4}{*}{0.5449} \\
\hline & Ethical conduct is valued highly & OCU2 & 0.7426 & \\
\hline & Unethical will be disciplined & OCU3 & 0.7541 & \\
\hline & Punishment for unethical behavior & OCU4 & 0.7584 & \\
\hline \multirow{3}{*}{$\begin{array}{l}\text { Fraud Intention } \\
\qquad(\mathrm{FI})\end{array}$} & Decrease expenses to improve revenues & FI1 & 0.6461 & \multirow{3}{*}{0.5700} \\
\hline & Misappropriation of asset & FI3 & 0.7631 & \\
\hline & Asking the tip to vendor & FI4 & 0.8427 & \\
\hline
\end{tabular}

Source: Data Analyzed

From the test results shown in Table 2 above, the value of each variable AVE exceeds 0.5 so that all variables have met the test of convergent validity. Discriminant validity is tested by comparing the value of the square

root of AVE in each variable and variable correlations with other variables in the model. AVE square root values in bold (Table 3 ) is greater than correlation between variables. It can be concluded that the test of discriminant validity has been fulfilled.

Table 3.

Composite Reliability and Correlation among Constructs

\begin{tabular}{|c|c|c|c|c|c|c|c|c|}
\hline & CR & FI & LOM & ML & OCO & OCU & RF & WE \\
\hline FI & 0.7972 & $\mathbf{0 . 7 5 5 0}$ & & & & & & \\
\hline LOM & 0.8615 & -0.1236 & $\mathbf{0 . 7 1 4 8}$ & & & & & \\
\hline ML & 0.8571 & -0.1566 & -0.1975 & $\mathbf{0 . 7 0 8 2}$ & & & & \\
\hline OCO & 0.8680 & -0.1357 & -0.1547 & 0.3063 & $\mathbf{0 . 8 2 9 3}$ & & & \\
\hline OCU & 0.8271 & -0.3800 & -0.0080 & 0.4625 & 0.2873 & $\mathbf{0 . 7 3 8 2}$ & & \\
\hline RF & 0.8902 & -0.3229 & -0.0597 & 0.0562 & 0.2881 & 0.2672 & $\mathbf{0 . 7 3 4 0}$ & \\
\hline WE & 0.8420 & -0.3142 & -0.1019 & 0.3998 & 0.2759 & 0.4671 & 0.2286 & $\mathbf{0 . 7 5 6 3}$ \\
\hline
\end{tabular}

Source: Data Analyzed

\section{Reliability Test}

To meet the test of reliability, each variable should have composite reliability $>0.7$. Results of composite reliability (CR) are shown in Table 3. All variables have value of composite reliable which exceed 0,7 . It means that all variables have met the test of reliability.

\section{Structural Model (Inner Model)}

Inner model consists of testing the value of R-Square (R2), t test statistic, and path coefficient. R-Square value (R2) shows the ability of research models to explain dependent variable. The result are 
Table 4.

$R^{2}$ Value

\begin{tabular}{|l|c|}
\hline \multicolumn{1}{|c|}{ Construct } & R Square \\
\hline Fraud Intention & 0.2380 \\
\hline
\end{tabular}

Source: Data Analyzed

This results of the research show that R-Square (R2) has a value 0.2380 or $23.80 \%$, which means research model is able to explain $23.80 \%$ fraud intention while $76.20 \%$ is explained by other variables. Test of path coefficient and $\mathrm{t}$ statistics are presented in Table 2 below.

\section{T-statistic test}

Test of path coefficient () and t statistics are presented in Table 5 below.
$0.31<1.64$. It means has no significant effect. Then, morality leadership (ML) positively related (0.0001) and not significant $(0.0008<$ 1.64). Work environment has a negative effect $(-0.1675)$ with a significant influence $(2.2464>$ 1.64). Religious faith has a negative influence $(-0.2350)$ with a significant influence (3.2014 > 1.64). Organizational culture negatively related to fraud intention (-0.2477) and has significant effect $(2.6949>1.64)$.

\section{Love of money to Fraud Intention (H1)}

Results of this research showed that the love of money negatively related to fraud intention. This result surprising us, why person with high love of money less to commit fraud.

Table 5.

Path Coefficient and t-value

\begin{tabular}{|c|c|c|c|c|}
\hline Hypotesis & Path & $\begin{array}{c}\text { Path } \\
\text { Coefficient }(\boldsymbol{\beta})\end{array}$ & t-value & Result \\
\hline H1 & LOM -> FI & $-0,1527$ & 1,2679 & Not Supported \\
\hline H2 & OCO -> FI & 0,0257 & 0,3100 & Not Supported \\
\hline H3 & ML -> FI & 0,0001 & 0,0008 & Not Supported \\
\hline H4 & WE -> FI & $-0,1675$ & 2,2464 & Supported \\
\hline H5 & RF -> FI & $-0,2350$ & 3,2014 & Supported \\
\hline H6 & OCU -> FI & $-0,2477$ & 2,6949 & Supported \\
\hline
\end{tabular}

Source: Data Analyzed

As shown in table 5, three hypotheses are supported while the other three are not. This study directly examine data from all respondents in the variables, and then tested directly to fraud intention. Based on the table above, the results show the love of money (LOM) have a negative influence $(-0.1527)$ but not significant because $\mathrm{t}$ value (1.2679 $<$ 1.64). Organizational commitment (OCO) has a positive influence $(0.0257)$ and t-value
Previous study found that the love of money is the root of evil (unethical behavior) but not in this research. Study of Tang and Chiu (2003) in Hong Kong employees, in a direct path of love of money to evil, love of money is the root of evil. Further, this study stated high employees' income have low of love of money.

Why this research don't show the same result?. Love of money doesn't motivate 
employees to commit fraud. Love of money just a feeling toward money for employees because in the employees' mind, life is not about money despite they need money in their life but money don't influence their mind to commit fraud. This result provides a statement that love of money doesn't become a motivator for employees to commit fraud. Love of money is an attitude towards money, but don't represent one's need, greed, or materialism. In respondents' perspective, love of money is not a motivator to unethical behavior because money don't represent people' successful and rich. In statistic result, love of money don't have positive influence significantly, it means there is still a tendency love of money to motivate employees to commit fraud.

\section{Organizational Commitment to Fraud Intention} (H2)

When examined about organizational commitment, Tang and Chiu (2003) explained that organizational commitment is formed from the pay satisfaction and not related to unethical behavior. This study examine the direct path of organizational commitment to fraud intention to use the organizational commitment questionnaire (OSQ). In this result, organizational commitment associated with fraud intention. It is interesting us because employee who has commitment to organization tends to commit fraud.

According to Mowday, Steers, and Porter (1979) employees who committed to organization maintain its membership in organization. Employee who has a high organizational commitment will keep their good name in organization and have high concern to organization. Employees will make the organization in good shape and want to provide their best performance so employees can do everything including fraud to make organization look better.

\section{Morality Leadership to Fraud Intention (H3)}

The findings of this study are a positive influence of morality leadership to fraud intention. It means a leader caused fraud in the employees level. Leader is a referent person to perform the behavior. In moral managers leadership is the ability to influence employees' behavior and beliefs about ethics. Leader has a fundamental role to shape and guiding among organization notions (Berson, Oreg, and Dvir 2008). Then, why the leader the basis of employees' fraud?. Researchers interviewed some respondents to clarify these results. They stated, leaders can create policies or targets to make organization better. The policy is given to employees and at this time employees have the pressure to meet the requirements of the leader. When employees have difficulties to fulfill, the employees tend to commit fraud. Statistical results show this effect is not significant, it means the leader still has ability to influence employees to prevent unethical behavior.

\section{Work Environment to Fraud Intention (H4)}

The finding asserts a good working environment would be a barrier to fraud. A favorable work environment will enhance creativity, ethical conduct, and performance. 
This result supporting research by Sardžoska and Tang (2012) that found a good work environment will prevent fraud in the organization. A favorable work environment will enhance job satisfaction and will prevent employees to commit fraud. A favorable, conducive, comfort, and mutual respect among employees in a work environment will motivate employees to conduct ethically and make low of opportunity to commit fraud. A ethical work environment influencing employees' mind to always act ethically.

\section{Religious Faith to Fraud Intention (H5)}

This research examines the direct path of religious faith to fraud intention. The finding is religious faith negatively related to fraud intention. Employees who have a high religious faith will not commit to fraud. Kennedy and Lawton (1998) found that religious avoiding unethical behavior and employees less to commit fraud because their belief to God. Employees think carefully before perform the behavior. They have a question "is that behavior prohibited or not by the God?". They will not to conduct the behavior if it is prohibited. Religious faith is important to make employees not to conduct unethical behavior. Why it is important?, unethical is one of behavior prohibited by the God. If employees belief to God, they automatically will not to perform it. They belief if they perform unethical they will get the sin and they far away in the God's way. So, organizations have an obligation to improve their religious faith to protect unethical (fraud) occur in organizations.
Organizational Culture to Fraud Intention (H6)

Organizational culture negatively associated to fraud intention. This result explain that a good organizational culture reduce opportunity employees to commit fraud. Previous research showed that a organizational culture can be a source of sustainable competitive advantage if these cultures valuable, rare, and imperfectly imitable. Organizations with valuable, rare, imperfectly imitable can obtain sustained superior financial performance, other attributes of a firm, and lead the organization's performance. According to Trevino and Brown (2004), an informal element of cultural systems are intangible aspects of the behavior such as norms of behavior consistent with ethical standards or code of conduct. Organizations need to obtain a good culture to establish a good personality so if employee perform unethical will feel confuse and automatically prevented by this organizational culture. Organizational culture is the best way to prevent fraud. Organizational culture is a system to guide all of organization member to conduct ethically and one of competitive advantage to reach organization's goals.

\section{CONCLUSION}

This research aims to understand factors influencing employees to create intention to commit fraud. This research find love of money negatively related to fraud intention. love of money is not root of unethical behavior. It means employee with high level of the love of money has a low intention to commit fraud. But, this result is not significant affecting fraud intention, 
so employees have possibility to commit fraud if they have high of love of money. Next, this research find organizational commitment positively related to fraud intention. Employees with high level of commitment tend to commit fraud but commitment is not significantly influencing fraud intention.

Morality leadership is positively and not significant influencing fraud intention. This result explains that leader can make employee to conduct fraud but this influence is very low. It means leader don't motivate employee to fraud but has opportunity to fraud caused the leader. The finding states work environment negatively affecting to fraud intention. It explains favorable environment can guide employee to conduct ethically and less to commit fraud.

Religious faith is negatively and significant influencing fraud intention. This result suggests if employee with highly religious faith has low possible to commit fraud. Religious faith guides employee to perform ethical behavior. This research found culture of organization negatively and significant related to fraud. Organizational culture has a important role to enhance moral of employee to conduct ethical behavior. The good organizational culture reduces employees' intention to fraud.

\section{Implication}

Research model in this research provide an interesting results and to understand the factors related to fraud. In this research, love of money is not the root of fraud. Previous study found the love of money is the root of fraud (Tang and Chiu 2003). Employees with the organization commitment tend to commit fraud. This research find work environment and organizational culture protect organization from fraud. Then, employees have high religious faith are not going to do unethical behavior. A favorable work environment and organizational culture will prevent fraud occur in organization. Organization need to create a conducive work environment to enhance creativity of employees. In addition, good organizational culture will guide employees to perform ethical behavior. Ethical behavior can be created if the leader shaping and guiding employees to behave ethically (Berson, Oreg, and Dvir 2008). Although the love of money is not the root of evil, organizations need to increase the employees' religious beliefs to prevent unethical behavior.

\section{Limitation}

This research is limited to some variables. They are love of money, organizational commitment, morality leadership, work environment, religious faith, and organization culture. This study used non-medical employees as a respondent not all employees in hospitals.. This results cannot be generalized because research with other respondent may have different results. This research only measure the factors associated with fraud intention but not the actual fraud. Results shows value of r-square is low, it means variables in this research cannot explain all factors related to fraud. 


\section{Future Research Direction}

This research gives a view to the next researcher to develop more variables so that the research is able to explain some factors that affect the intention of fraud. Variables in this research cannot explain all factors of fraud shown by the low value of $\mathrm{R}$ square. Researchers suggest future research to add variables related to income, pay satisfaction, and job satisfaction. Increase the number of respondents to make the research more comprehensive. Use other organization to understand intention of fraud in other organization.

\section{REFERENCES}

ACFE. 2014. "Report to the Nation on Occupational Fraud and Abuse: 2014 Global Fraud Study."

Ajzen, I. 1991. "The Theory of Planned Behavior." Organizational Behavior and Human Decision Processes 50: 179-211.

Allen, N J, and J P Mayer. 1990. "The Measurement and Antecedents of Affective, Continuance, and Normative Commitment to the Organization'." Journal of Occupational Psychology 63: $1-18$.

Amabile, T M, R Conti, H Coon, and M Herron. 1996. "Assessing the Work Environment for Creativity." The Academy of Management Journal 39 (5): 1154-84.
Bakshi, A, K Kumar, and E Rani. 2009. "Organizational Justice Perception as Predictor of Job Satisfaction and Organizational Commitment." International Journal of Business and Management 4 (9): 145-54.

Berson, Y, S Oreg, and T Dvir. 2008. "CEO Values, Organizational Culture an Fim Outcomes.” Journal of Organizational Behavior 29 (5): 615-33.

Brown, Michael E., Linda K. Trevino, and David A. Harrison. 2005. "Ethical Leadership: A Social Learning Perspective for Construct Development and Testing." Organizational Behavior and Human Decision Processes 97 (2): 117-34. doi:10.1016/j.obhdp.2005.03.002.

Chen, H, and S Chen. 2013. "Measurement the Effect of Safety Management System Practices, Morality Leadership and SelfEfficacy on Pilot's Safety Behavior: Safety Motivation as a Mediator." Safety Science 62: 376-85.

Ciulla, J B. 1995. "Leadership Ethics: Mapping the Teritory." Business Ethics Quarterly 5 (1): 5-28.

Cohen, D. 1993. "Creating and Maintaining Ethical Work Climates: $A$ in the Workplace and Implication for Managing Change." Business Ethics Quarterly 3 (4): 343-58. 
Du, L, and Thomas Li-ping Tang. 2005. "Measurement Invariance across Gender and Major: The Love of Money among University Student in People's Republic of China." Journal of Business Ethics 59 (3): 281-93.

Fishbein, M, and I Ajzen. 1975. Beliefs, Attitude, Intention, and Behavior: An Introduction to Theory and Research. Reading: Addison-Wisley.

Glock, C Y, and R Stark. 1965. Religion and Society in Tension. San Fransisco: Rand McNally.

Grandberg, D, and S Holmberg. 1990. “The Intention-Behavior Relationship Among U.S. and Swedish Voters'." Social Psychology Quarterly 53 (1): 44-54.

Kaptein, M. 2008. "Developing and Testing a Measure for the Ethical Culture of Organizations: The Corporate Ethical Virtues Model." Journal of Organizational Behavior 29 (7): 923-47. doi:10.1002/job.520.

Kennedy, E J, and L Lawton. 1998. "Religiousness and Business Ethics." Journal of Business Ethics 17 (2): 163-75.

Ladkin, D. 2008. “"Leading Beautifully : How Mastery, Congruence and Purpose Create the Aestic of Embodied Leadership Practice." The Leadership Quarterly 50 (1): 31-41.
Luna-Arocas, R, and T. Tang. 2004. "The Love of Money, Satisfaction, and the Protestant Work Ethic: Money Profiles among University Professors in the U.S.A and Spain.” Journal of Business Ethics 50 (4): 329-54.

Mayer, D. M, M. Kuenzi, and R. L. Greenbaum. 2011. "Examining the Link Between Ethical Leadership and Employee Misconduct :" Journal of Business Ethics 95: 7-16. doi:10.1007/s10551-011-07940.

Mowday, R. T., R. M. Steers, and L. W Porter. 1979. "The Measurement of Organizational Commitment." Journal of Vocational Behavior 14: 224-47.

Robinson, S. L, and R. J. Bennett. 1995. "A Typology of Deviant Workplace Behaviors: A Multidimensional Scaling Study." The Academy of Management Journal 38 (2): 555-72.

Sardžoska, E, and T Tang. 2009. "Testing a Model of Behavioral Intentions in the Republic of Macedonia: Differences between the Private and the Public Sectors." Journal of Business Ethics 87 (4): 495-517.

Sardžoska, Elisaveta Gjorgji, and Thomas Li Ping Tang. 2012. "Work-Related Behavioral Intentions in Macedonia: Coping Strategies, Work Environment, Love of Money, Job Satisfaction, and Demographic Variables." Journal of Business Ethics 108 (3): 373-91. 
Schein, E. 2004. Organization Culture and Leadership. San Fransisco: Jossey-Bass.

Taiwo, A S. 2009. "The Inflence of Work Environment on Workers Productivity: A Case of Selected Oil and Gas Industry in Lagos, Nigeria." African Journal of Business Management 4 (3): 299-307.

Tang, T, R Luna-Arocas, T Sutarso, and D S Tang. 2004. "Does the Love of Money Moderate and Mediate Theincome-Pay Satisfaction Relationship?" Journal of Managerial Psychology 19 (2): 111-35.

Tang, Thomas Li-ping. 2007. "Income and Quality of Life: Does the Love of Money Make a Different?" Journal of Business Ethics2 72 (4): 375-93.

Tang, T, and Y. Chen. 2008. "Intelligence vs. Wisdom: The Love of Money, Machiavellianism, and Unethical Behavior across College Major and Gender." Journal of Business Ethics 82 (1): 1-26.

Tang, T, T. Sutarso, G. M. W. Davis, D. Dolinski, A. H. S. Ibrahim, and S. L. Wagner. 2008. "To Help or Not to Help: The Good Samaritan Effect and the Love of Money on Helping Behavior." Journal of Business Ethics 82 (4): 865-87.

Tang, T, and R. K. Chiu. 2003. "Income, Money Ethic, Pay Satisfaction, Commitment, and Unethical Behavior: Is the Love of Money the Root of Evil for Hong Kong Employees?" Journal of Business Ethics 46 (1): 13-30.
Toor, S., and G. Ofori. 2009. "Ethical Leadership: Examining the Relationships with Full Range Leadership Model, Employee Outcomes, and Organizational Culture." Journal of Business Ethics 90 (4): 533-47.

Transparency International. 2014. "Corruption Perception Index 2014: Results. http:// Www.transparency.org/cpi2014/results (Accessed December 28, 2014)"

Trevino, L K, and ME Brown. 2004. "Managing to Be Ethical: Debunking Fie Business Ethic Myth." Academy of Management Executive 18 (2): 69-81.

Vries-Schot, M R, J Pieper, and M Van Uden. 2012. "Mature Religiosity Scale: Validity of a New Questionnaire." European Journal of Mental Health 7: 57-71.

Yilmaz, O, and H. G. Bahçekapili. 2015. "Journal of Experimental Social Psychology Without God, Everything Is Permitted ?. Journal of Experimental Social Psychology 58: 95-100. 
Aditya Pandu Wicaksono : Factors Influencing Employees To Commit Fraud,.....

Page 1-18 